glaciers. The Mammoth may be supposed to have passed between Asia and America at this time. At a later date, when Behring Straits were opened and the perennial accumulation of snow ceased on the lowlands, the clay was probably carried down from the highlands and deposited during the overflow of rivers. Over this land the Mammoth roamed, and wherever local areas of decay of ice arose, bogs would be produced which served as veritable sink-traps. The author considers it probable that the accumulation of "ground-ice" was coincident with the second (and latest) epoch of maximum glaciation, which was followed by an important subsidence in British Columbia.

\title{
COREFSPONDEINCF.
}

\section{THE RECENT GEOLOGICAL HISTORY OF THE ARCTIC LANDS.}

In Sir Henry Howorth's article, bearing the above title, which appeared in the November Number of this Magazina, he writes (at page 499), "so far as we can make out, the climate (of the Circumpolar Lands) has been becoming more and more severe in historic times, and that in the Pleistocene age, so far as we have evidence, the climate of the Polar area was more, and not less, temperate than now." .... "This again is confirmed by such facts as the occurrence of the great sea-cows, which Steller discovered around Behring's Island, in a latitude far away from all their relatives and congeners. They are essentially animals which thrive under temperate or subtropical conditions, and this colony, so lately occurring in the Nortb Pacific, seems to point clearly to the climate of that region having been recently milder."

Quoting from my paper on Fossil Sirenia (Groc. Mag. 1885, p. 423), "Assuming, as I think we may, that the living Sirenia belong exclusively to the tropical regions of the earth, and that Rhytina, in its boreal home, was simply a surviving relic from the past, a sort of geological 'outlier,' we must conclude that the presence of about 12 genera and 27 species of fossil Sirenia, as widely distributed (over Europe and America) then, as the recent forms are (within the tropics) at the present day, but with a range from the tropic of Cancer up to (nearly) $60^{\circ}$ of north latitude, attests the former northern extension of subtropical conditions of climate which must have prevailed over Europe, Asia, and North America in Tertiary times."

It seems to me that the only doubtful point is as to when and how long in Tertiary times this warmer condition of climate lasted. Nor must we omit to bear in mind that the survival of "Steller's sea-cow" (Rhytina gigas), down to 1780, around the shores of Behring and Copper Islands, in $55^{\circ}-60^{\circ} \mathrm{N}$. latitude, is very largely, if not wholly, due to the "Kuro-Sivo," or "Black River," the Gulfstream of the Northern Pacific, which, by its warm waters, encourages the growth so far to the northward of those vast submarine meadows of succulent Algæ on which these Phytophagous Sirenians subsisted. Nor has the changing climate or want of food caused the elimination 
of this last survivor of Tertiary times, but the hand of Man the destroyer. The wide distribution of numerous species of Sirenia in Tertiary times over Europe and America is, however, a powerful argument in favour of the former higher temperature of our Northern hemisphere.

Henry Woodward.

\section{THE CARBON-CRUST ON FOSSIL PLANTS.}

Sir,-It is well known that Fossil plants when found in sandstone are generally entirely covered with a thin layer of nearly pure carbon; in the case of Calamites, etc., in the Coal-measure sandstones the layer is often not more than about $\frac{1}{20}$ of an inch in thickness. It very readily falls away, and it is only in rare cases that it adheres to the sandstone cast. I should like to propose some questions concerning this carbonaceous covering to your readers. (1) Why is the whole of the carbonaceous residue in wellpreserved fossils confined to the outside of the cast? (2) Does the carbonaceous layer represent the whole of the carbon of the tissue of the plant? (3) Why, in comparatively soft and little altered freestones, should the carbonaceous layer exhibit such a baked or charred appearance?

A. Wilmore.

Wesleyan Schoots, Trawtre, Colne, Lancashire, November $8 t h, 1893$.

\section{OEITUART.}

JOHN HOOKE TAUNTON, M.INST.C.E., F.G.S.

EARLY in the present year ${ }^{1}$ we lost by death Mr. John Hooke Taunton, M.Inst.C.E., F.G.S., of Stroud. Mr. Taunton had an intimate acquaintance with the water-bearing strata of the Cotteswold Hills, and furnished some valuable information to the Report of the Commissioners on Water Supply (1869). He was for many years local engineer to the Thames and Severn Canal Company, and also consulting engineer to the Stroud Local Board of Health. $\mathrm{He}$ contributed several papers to the Proceedings of the Cotteswold Naturalists' Club, of which he was an active member: among these were papers on the Hydrology of the Cotteswolds, on the Geology of the Sapperton Tunnel, on the Malmesbury Waterworks, and on the Dynamic Geology of Palestine.

\section{THE REV. H. W. CROSSKEY, LL.D., F.G.S.}
BoRN 1826.
Died OCTOBER 1st, 1893.

Is Dr. H. W. Crossiey we have to record the loss of one who was a most ardent student of Glacial Geology and the author of a valuable series of Reports on the Erratic blocks of this country, communicated during the past 20 years to the British Association. He paid much attention to the post-Tertiary deposits of the Clyde Valley, and was associated with David Robertson and Dr. G. S. Brady in describing the post-Tertiary Entomostraca in the Palæontographical Society's Volume for 1874. Whilst resident in Glasgow he contributed many papers to the Geological Society of Glasgow. He died at his residence, Edgbaston, Birmingham, Oct. 1st, 1893.

\footnotetext{
1 January 31st, 1893.
} 